Marquette University

e-Publications@Marquette

Biomedical Sciences Faculty Research and

Publications

Biomedical Sciences, Department of

$12-2010$

\title{
Levo-Tetrahydropalmatine Attenuates Cocaine Self- Administration under a Progressive-Ratio Schedule and Cocaine Discrimination in Rats
}

\author{
John R. Mantsch \\ Marquette University, john.mantsch@marquette.edu \\ Samantha Wisniewski \\ Marquette University \\ Oliver Vranjkovic \\ Marquette University \\ Corey Peters \\ Marquette University \\ Amanda Becker \\ Marquette University
}

See next page for additional authors

Follow this and additional works at: https://epublications.marquette.edu/biomedsci_fac

Part of the Neurosciences Commons

\section{Recommended Citation}

Mantsch, John R.; Wisniewski, Samantha; Vranjkovic, Oliver; Peters, Corey; Becker, Amanda; Valentine, Abbey; Li, Shi-Jiang; Baker, David A.; and Yang, Zheng, "Levo-Tetrahydropalmatine Attenuates Cocaine Self-Administration under a Progressive-Ratio Schedule and Cocaine Discrimination in Rats" (2010). Biomedical Sciences Faculty Research and Publications. 10.

https://epublications.marquette.edu/biomedsci_fac/10 


\section{Authors}

John R. Mantsch, Samantha Wisniewski, Oliver Vranjkovic, Corey Peters, Amanda Becker, Abbey Valentine, Shi-Jiang Li, David A. Baker, and Zheng Yang 


\title{
Levo-Tetrahydropalmatine Attenuates Cocaine Self- Administration under a Progressive- Ratio Schedule and Cocaine Discrimination in Rats
}

\author{
John R. Mantsch \\ Department of Biomedical Sciences, Marquette University \\ Milwaukee, WI \\ Samantha Wisniewski \\ Department of Biomedical Sciences, Marquette University \\ Milwaukee, WI \\ Oliver Vranjkovic \\ Department of Biomedical Sciences, Marquette University \\ Milwaukee, WI \\ Corey Peters \\ Department of Biomedical Sciences, Marquette University \\ Milwaukee, WI \\ Amanda Becker \\ Department of Biomedical Sciences, Marquette University \\ Milwaukee, WI
}

Pharmacology Biochemistry and Behavior, Vol. 97, No. 2 (December 2010): pg. 310-316. DOI. This article is (C) Elsevier and permission has been granted for this version to appear in e-Publications@Marquette. Elsevier does not grant permission for this article to be further copied/distributed or hosted elsewhere without the express permi ssion from Elsevier. 
NOT THE PUBLISHED VERSION; this is the author's final, peer-reviewed manuscript. The published version may be accessed by following the link in the citation at the bottom of the page.

\author{
Abbey Valentine \\ Department of Biomedical Sciences, Marquette University \\ Milwaukee, WI \\ Shi-Jiang Li \\ Department of Biophysics, Medical College of Wisconsin, \\ Milwaukee, WI \\ David A. Baker \\ Department of Biomedical Sciences, Marquette University \\ Milwaukee, WI \\ Zheng Yang \\ Beijing Institute of Basic Medical Sciences \\ Beijing, China
}

\begin{abstract}
Levo-tetrahydropalmatine (I-THP) is an alkaloid found in many traditional Chinese herbal preparations and has a unique pharmacological profile that includes dopamine receptor antagonism. Previously we demonstrated that $I$-THP attenuates fixed-ratio (FR) cocaine selfadministration (SA) and cocaine-induced reinstatement in rats at doses that do not alter food-reinforced responding. This study examined the effects of $I$ THP on cocaine and food SA under progressive-ratio (PR) schedules of reinforcement and the discriminative stimulus effects of cocaine. In adult male Sprague-Dawley rats self-administering cocaine $(0.5$ or $1.0 \mathrm{mg} / \mathrm{kg} / \mathrm{inf})$, I-THP significantly reduced breaking points at the $1.875,3.75$ and $7.5 \mathrm{mg} / \mathrm{kg}$ doses. I-THP also reduced the breaking points and response rates for PR SA of sucrose-sweetened food pellets, although the decrease was significant only at the $7.5 \mathrm{mg} / \mathrm{kg} /$-THP dose. In rats trained to discriminate cocaine $(10 \mathrm{mg} / \mathrm{kg}$, ip) from saline, l-THP $(1.875,3.75$ and $7.5 \mathrm{mg} / \mathrm{kg})$ produced a rightward shift in the dose-response curve for cocaine generalization. During generalization testing, I-THP reduced response rate, but only at the $7.5 \mathrm{mg} / \mathrm{kg}$ dose. I-THP also prevented substitution of the dopamine D2/D3 receptor agonist, (+/-) 7OH-DPAT, for cocaine suggesting a potential role for antagonism of D2 and/or D3 receptors in the effects of I-THP. These data further demonstrate that ITHP attenuates the reinforcing and subjective effects of cocaine at doses that do not produce marked motor effects and provide additional evidence that $I$ THP may have utility for the management of cocaine addiction.
\end{abstract}

Pharmacology Biochemistry and Behavior, Vol. 97, No. 2 (December 2010): pg. 310-316. DOI. This article is (C) Elsevier and permission has been granted for this version to appear in e-Publications@Marquette. Elsevier does not grant permission for this article to be further copied/distributed or hosted elsewhere without the express permission from Elsevier. 
NOT THE PUBLISHED VERSION; this is the author's final, peer-reviewed manuscript. The published version may be accessed by following the link in the citation at the bottom of the page.

Keywords: dopamine, antagonist, discriminative stimulus, D2 receptor, D3 receptor, THP, 7-OH-DPAT

\section{Introduction}

Although a number of potentially promising medications have been identified for treating drug-dependent individuals (Vocci et al., 2005), a demand still exists for new and more effective medicinal approaches. Despite their potential efficacy, traditional herbal preparations are often not considered to be viable options for treating drug addiction, due in part to the paucity of reliable clinical and preclinical studies examining their utility. However, there has been a recent effort by many to test the effectiveness of such agents and their active constituents using accepted preclinical disease models and well-controlled clinical trials (De Smet, 2002; Ernst, 2005).

Tetrahydropalmatine (THP) is a tetrahydroprotoberberine (THPB) isoquinoline alkaloid and a primary active constituent of herbal preparations containing plant species of the genera Stephania (Menispermaceae family) and Corydalis (Fumariaceae family) including Bin Ju Huan, Yan Hu Suo, Di Bu Long and Hua Jian Jiu Teng. Two of these species, Corydalis ambigua (yan hu suo) and Stephania tetranda (fang ji) are among the 50 fundamental herbs in Chinese herbology and have been used traditionally for their sedative, neuroleptic and analgesic properties (Ding, 1987). In particular, the levo isomer of THP (I-THP) appears to contribute to many of the therapeutic effects of these preparations through its actions at DA receptors (Jin, 1987; Chu et al., 2008).

A large body of data indicates that I-THP is an antagonist at dopamine (DA) D1 and D2 receptors (Jin et al., 1986; Jin, 1987; Xu et al., 1989; Wu et al., 1990; Zhu et al., 1991; Huang and Jin, 1992; Sun et al., 1992; Guo et al., 1997; Hu and Jin, 1999; Mantsch et al., 2007). Considering the involvement of dopaminergic neurotransmission in cocaine abuse and addiction (Volkow et al., 2004; Anderson and Pierce, 2005), compounds such as I-THP which antagonize DA receptors have long been thought to represent potential medications for the management of cocaine addiction. However, despite its promise, this approach has been largely unsuccessful for treating cocaine addiction due to lack of efficacy and/or the occurrence

Pharmacology Biochemistry and Behavior, Vol. 97, No. 2 (December 2010): pg. 310-316. DOI. This article is (C) Elsevier and permission has been granted for this version to appear in e-Publications@Marquette. Elsevier does not grant permission for this article to be further copied/distributed or hosted elsewhere without the express permission from Elsevier. 
of use limiting side effects such as sedation and anhedonia, attributable in part to undesirable pharmacological profiles (Platt et al., 2002). Compared to many other DA receptor antagonist drugs, I-THP has lower affinity for D2 DA receptors relative to D1 receptors (Jin, 1987). I-THP also binds to D3 DA receptors (Mantsch et al., 2007), likely functioning as an antagonist, and has secondary actions at a number of non-DA receptors (see e.g., Lu et al., 1996; Halbsguth et al., 2003). The unique pharmacological profile of I-THP distinguishes it from other DA antagonist drugs and may make it a more suitable medication for treating cocaine addiction.

We (Mantsch et al., 2007) and others (Xi et al., 2007) have recently demonstrated that I-THP attenuates cocaine selfadministration (SA; Mantsch et al., 2007; Xi et al., 2007), cocaineevoked reinstatement (Mantsch et al., 2007) and cocaine-induced reductions in intracranial self-stimulation (ICSS) thresholds (Xi et al., 2007) in rats at doses that produce little or no impairment of motor function. Along with the findings of a recent preliminary clinical trial demonstrating that I-THP attenuates craving and relapse in recovering heroin addicts (Yang et al., 2008), these data suggest that further investigation of the utility of I-THP for the treatment of cocaine addiction is warranted.

In the present study we investigated the ability of I-THP isolated from the roots of Stephania delavayi Diels (Di Bu Long) acquired from Yunnan province in China to attenuate cocaine's reinforcing and subjective properties by testing for I-THP effects on cocaine SA under a progressive ratio (PR) schedule and cocaine generalization in rats trained to discriminate cocaine from saline. In an attempt to further dissociate /-THP interference with cocaine's subjective/reinforcing effects from its sedative/motor effects, we also examined the effects of I-THP on food-reinforced responding either concurrently with generalization testing using the drug discrimination approach or in separate rats trained to self-administer sucrose-sweetened food pellets under an identical PR schedule of reinforcement. Finally, the potential role of DA D2/D3 receptor antagonism in the effects of I-THP was investigated by examining the effects of I-THP on the cocaine-like discriminative stimulus effects of the D2/D3 receptor agonist drug, $(+/-)$ 7-OH-DPAT.

Pharmacology Biochemistry and Behavior, Vol. 97, No. 2 (December 2010): pg. 310-316. DOI. This article is (C) Elsevier and permission has been granted for this version to appear in e-Publications@Marquette. Elsevier does not grant permission for this article to be further copied/distributed or hosted elsewhere without the express permission from Elsevier. 
NOT THE PUBLISHED VERSION; this is the author's final, peer-reviewed manuscript. The published version may be accessed by following the link in the citation at the bottom of the page.

\section{Methods}

\subsection{Subjects}

Fifty-six adult male Sprague-Dawley rats were used for the study. Thirteen total rats were used to test the effects of I-THP on the discriminative stimulus effects of cocaine. Twenty-four total rats were used to test the effects of I-THP on PR cocaine SA. Nineteen total rats were used to test the effects of I-THP on PR food SA. All rats were housed singly in a temperature- and humidity-controlled, AAALACaccredited animal facility under a reversed $12 \mathrm{~h} / 12 \mathrm{~h}$ light/dark cycle (lights on at 7:00 PM). For the drug discrimination and food PR SA experiments, rats were food restricted and maintained at $90 \%$ of their free-feeding body weight determined at the start of the study. For the cocaine PR SA study, rats had free access to food, except when in the experimental chambers. All procedures were carried out in accordance with the Guide for the Care and Use of Laboratory Animals as adopted and promulgated by the $\mathrm{NIH}$.

\subsection{Drugs}

Cocaine $\mathrm{HCl}$ was acquired from the National Institute on Drug Abuse (NIDA) through the NIDA Drug Supply Program. I-THP was isolated from the crushed and dried tuberous roots of Stephania delavayi Diels (Di Bu Long) grown in Yunnan province in China and was acquired from the Beijing Basic Science Research Institute (Beijing, China). The purity of the isolated /-THP was greater than $99 \%$, as determined using HPLC. Cocaine was dissolved in saline $(0.9 \% \mathrm{NaCl}$ solution). I-THP was dissolved in sterile water and administered at doses of $1.875,3.75$ and $7.5 \mathrm{mg} / \mathrm{kg}$, ip. Some rats were also tested for drug discrimination in combination with a 15 $\mathrm{mg} / \mathrm{kg}$ /-THP dose (data not shown). However, due to high levels of sedation, these rats were unable to complete the response requirements for testing. For this reason we limited all subsequent testing to the lower I-THP doses. (+/-) 7-OH-DPAT (7-hydroxy-N,Ndin-propylaminotetralin) was purchased from Sigma-Aldrich and was dissolved in saline and was administered at doses of $0.1,0.3$, and 1.0 $\mathrm{mg} / \mathrm{kg}$ (ip).

Pharmacology Biochemistry and Behavior, Vol. 97, No. 2 (December 2010): pg. 310-316. DOI. This article is (C) Elsevier and permission has been granted for this version to appear in e-Publications@Marquette. Elsevier does not grant permission for this article to be further copied/distributed or hosted elsewhere without the express permission from Elsevier. 
NOT THE PUBLISHED VERSION; this is the author's final, peer-reviewed manuscript. The published version may be accessed by following the link in the citation at the bottom of the page.

\subsection{Apparatus}

Twenty plastic and stainless steel operant conditioning chambers encased in sound attenuating cubicles (MED-Associates Inc., St Albans, VT) were used. Chambers were equipped with retractable levers with stimulus lights located above them. Two levers and their corresponding stimulus lights were mounted on the front wall of the chamber. A food pellet dispenser receptacle was located between the two levers on the front wall. Cubicles were equipped with exhaust fans that provided ventilation and white noise to mask extraneous sound. The operant conditioning chambers were interfaced with computers containing Med-PC software for automated control of testing conditions and data collection.

\subsection{Progressive Ratio Self-Administration}

\subsubsection{Catheterization Surgery}

For the PR cocaine SA experiment, rats were implanted with chronic indwelling catheters under ketamine $\mathrm{HCl}(100 \mathrm{mg} / \mathrm{kg}$, ip, Fort Dodge Animal Health, Fort Dodge, IA) and xylazine (2 mg/kg, ip, Lloyd Laboratories, Shenandoah, IA) anesthesia as previously reported

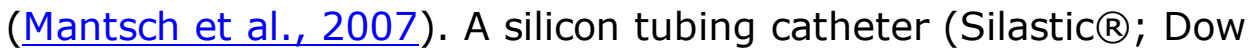
Corning Co., Midland, MI; 0.64 mm i.d.; $1.19 \mathrm{~mm}$ o.d.) was inserted into the right posterior facial vein and down into the jugular vein so that it terminated at right atrium. The catheter was sutured to the vein and continued subcutaneously to the animal's back where it exited 2 $\mathrm{cm}$ posterior to the scapula via a back-mounted 22-gauge guide cannula (Plastics One Inc., Roanoke, VA) attached using dental acrylic to a piece of polypropylene monofilament surgical mesh (Atrium Medical, Co., Hudson, $\mathrm{NH}$ ) to permit connection of a polyethylene delivery line $(0.58 \mathrm{~mm}$ i.d. $\times 1.27 \mathrm{~mm}$ o.d.; Plastics One Inc., Roanoke, VA) encased in a stainless steel spring leash (Plastics One). The delivery line was connected to a $30-\mathrm{ml}$ syringe in a motor-driven pump (Razel, Stamford, CT) via a leak-proof fluid swivel (Instech Lab. Inc., Plymouth Meeting, PA) suspended above the chamber to allow drug solution delivery. The swivel and leash assembly was counterbalanced to permit relatively unrestrained movement. Rats were allowed to recover for at least three days prior to SA testing during

Pharmacology Biochemistry and Behavior, Vol. 97, No. 2 (December 2010): pg. 310-316. DOI. This article is (C) Elsevier and permission has been granted for this version to appear in e-Publications@Marquette. Elsevier does not grant permission for this article to be further copied/distributed or hosted elsewhere without the express permission from Elsevier. 
time they were provided acetaminophen $(480 \mathrm{mg} / \mathrm{L})$ in their drinking water. After implantation, rats were injected with a sterile cefazolin antibiotic solution (15 mg, iv; West-Ward Pharmaceutical Co., Eatontown, NJ) each day that they were tested, until the end of the study. Catheters were filled daily with a heparin solution (83 i.u./ml; Elkins-Sinn, Inc., Cherry Hill, NJ) and capped whenever the leash/delivery line assembly was disconnected.

\subsubsection{Effects of I-THP on Progressive Ratio Cocaine Self- Administration}

Rats were initially trained to press a lever under a FR1 schedule of food pellet reinforcement prior to catheter implantation. Following recovery from surgery, rats were trained to self-administer cocaine ( 1.0 or $0.5 \mathrm{mg} / \mathrm{kg} / \mathrm{inf}$ delivered over $5 \mathrm{sec}$ ) by pressing the active lever under a FR1 schedule. Drug availability was signaled by illumination of the house light in the chamber. During the drug infusion, the houselight was turned off and the stimulus light above the lever was illuminated. Each infusion was followed by a $10-\mathrm{sec}$ time-out period during which the stimulus and house lights were off. Once stable SA was observed (responding within $10 \%$ of the mean over 3 consecutive sessions), rats were switched to a PR schedule. Under this schedule the response requirement for cocaine delivery was increased with successive infusions using the following progression: $1,2,4,6,9,12,15,20,25,32,40,50,62,77,95,118,145,178,219,268,328$, $402,492,603,737,901,1102,1347,1646,2012$ (Richardson and Roberts, 1996). The progression continued until the tested rat failed to complete the ratio requirements within a $1-\mathrm{h}$ period. The breaking point was defined as the number of infusions self-administered prior to failure to meet the ratio requirements. Once stable PR SA was observed (breaking points within $10 \%$ of the mean over 3 consecutive sessions), the effects of I-THP were tested by pre-treating rats with ITHP $(1.875,3.75$ or $7.5 \mathrm{mg} / \mathrm{kg}$, ip) or vehicle 30 minutes prior to PR SA testing. Initially 18 rats were tested for the effects of vehicle and all three $/$-THP doses on PR SA of $1.0 \mathrm{mg} / \mathrm{kg} / \mathrm{inf}$ cocaine. Subsequently, in order to determine the relationship between the dose of cocaine available for SA and the effects of I-THP, another group of six rats was tested for the effects of vehicle and 1.875 and $3.75 \mathrm{mg} / \mathrm{kg} /$-THP on PR $\mathrm{SA}$ of $0.5 \mathrm{mg} / \mathrm{kg} / \mathrm{inf}$ cocaine.

Pharmacology Biochemistry and Behavior, Vol. 97, No. 2 (December 2010): pg. 310-316. DOI. This article is (C) Elsevier and permission has been granted for this version to appear in e-Publications@Marquette. Elsevier does not grant permission for this article to be further copied/distributed or hosted elsewhere without the express permission from Elsevier. 
NOT THE PUBLISHED VERSION; this is the author's final, peer-reviewed manuscript. The published version may be accessed by following the link in the citation at the bottom of the page.

\subsubsection{Effects of I-THP on Progressive Ratio Food Self- Administration}

In order to examine the effects of I-THP on PR SA of a non-drug reinforcer, separate groups of rats were trained to self-administer sucrose-sweetened food pellets (45 mg; BioServ) under a PR schedule identical to that used for cocaine SA. Once stable PR SA was observed in these rats, they were tested for the effects of I-THP as described above. Thirteen rats were tested for the effects of vehicle and 3.75 and $7.5 \mathrm{mg} / \mathrm{kg} /$-THP on PR food SA. A separate group of seven rats was tested for the effects of vehicle and $1.875 \mathrm{mg} / \mathrm{kg}$ l-THP on PR food SA.

\subsection{Drug Discrimination}

A total of 13 rats were trained to discriminate cocaine (10 $\mathrm{mg} / \mathrm{kg}$, ip) from saline $(0.9 \% \mathrm{NaCl})$ using a 2-lever FR20 sucrosesweetened food pellet (45 mg; BioServ, Frenchtown, NJ) reinforced drug discrimination design similar to that previously described (Mantsch and Goeders, 1999). These rats were food restricted and maintained at $90 \%$ of their initial free-feeding body weights. For each rat, one lever on the front wall on the chamber was designated as the cocaine-appropriate lever and the other as the saline-appropriate lever. Initially, rats were trained to press each of the levers under a FR1 schedule during separate sessions on alternating days. Once rats consistently acquired at least 100 food pellets during both -left and right lever sessions, errorless training began. During errorless training, rats were injected with $10 \mathrm{mg} / \mathrm{kg}$ cocaine or saline (ip) 15 min prior to the training session during which only the designated treatmentappropriate lever was available (i.e., extended) and active and the corresponding stimulus light illuminated. Errorless training sessions last for $30 \mathrm{~min}$ or until 100 reinforcers were delivered. Training began under an FR1 schedule of reinforcement and this ratio was gradually increased to FR20. Once 100 food pellets were acquired under the FR20 schedule of reinforcement within 30 minutes after both cocaine and saline treatments, discrimination training began. During discrimination training, both levers were extended into the chamber and their corresponding stimulus lights were illuminated, but only responding on the treatment-appropriate lever was reinforced under

Pharmacology Biochemistry and Behavior, Vol. 97, No. 2 (December 2010): pg. 310-316. DOI. This article is (C) Elsevier and permission has been granted for this version to appear in e-Publications@Marquette. Elsevier does not grant permission for this article to be further copied/distributed or hosted elsewhere without the express permission from Elsevier. 
the FR20 schedule. There were no programmed consequences of responding on the treatment inappropriate lever. Discrimination training continued until at least $85 \%$ of all responses prior to the delivery of the first reinforcer was on the treatment-appropriate lever for at least 9 out of 10 consecutive sessions. Throughout training, which was conducted five to six days weekly, the sequence of saline and cocaine exposure was randomized. However, neither cocaine nor saline treatment was administered for more than two consecutive training sessions.

\subsubsection{Effects of I-THP on Cocaine Discrimination}

Of the 13 rats that were trained, seven were tested for the effects of 3.75 and $7.5 \mathrm{mg} / \mathrm{kg} /$-THP and vehicle on cocaine discrimination. The remaining six were tested initially for the effects of $1.875 \mathrm{mg} / \mathrm{kg} /$-THP on cocaine discrimination and then were tested later for the effects of I-THP on ( \pm ) 7-OH-DPAT substitution (see section 2.5.2). Generalization testing was conducted twice weekly, usually on Tues and Fri. During generalization test sessions, both levers were extended and both stimulus lights illuminated. These sessions were terminated immediately following 20 responses on either lever (combined) with no food pellet delivery, or after 30 min elapsed. Generalization was defined as the percent of total responses (i.e., 20) emitted on the cocaine-appropriate lever. The effects of ITHP on cocaine generalization were tested by examining cocaineappropriate responding during test sessions preceded by administration of various cocaine doses $(0,1.25,2.5,5.0$, and 10.0 $\mathrm{mg} / \mathrm{kg}$, ip) after treatment with $/$-THP $(1.875,3.75$ or $7.5 \mathrm{mg} / \mathrm{kg}$, ip) or vehicle $30 \mathrm{~min}$ prior to cocaine delivery. Generalization test sessions were separated by additional training sessions during which rats were required to display $85 \%$ treatment-appropriate responding for at least two consecutive sessions (one cocaine and one saline). The sequences of cocaine and I-THP dose testing were counterbalanced according to a Latin square design to avoid potential sequence effects. During generalization testing, response rate (resp/min) was also recorded to permit concurrent examination of motor effects.

Pharmacology Biochemistry and Behavior, Vol. 97, No. 2 (December 2010): pg. 310-316. DOI. This article is (C) Elsevier and permission has been granted for this version to appear in e-Publications@Marquette. Elsevier does not grant permission for this article to be further copied/distributed or hosted elsewhere without the express permission from Elsevier. 
NOT THE PUBLISHED VERSION; this is the author's final, peer-reviewed manuscript. The published version may be accessed by following the link in the citation at the bottom of the page.

\subsubsection{Effects of I-THP on ( \pm ) 7-OH-DPAT Substitution for Cocaine}

To examine the potential role of DA D2 and D3 receptor antagonism in the effects of $I$-THP on cocaine discrimination, six rats were tested for the effects of $I$-THP on the substitution of the DA D2/D3 receptor agonist, $( \pm) 7-\mathrm{OH}-\mathrm{DPAT}$ for cocaine in rats trained to discriminate $10 \mathrm{mg} / \mathrm{kg}$ cocaine from saline. These six rats were also used earlier to test for the effects of $1.875 \mathrm{mg} / \mathrm{kg} /$-THP on cocaine discrimination. $( \pm)$ 7-OH-DPAT $(0.1,0.3$ or $1 \mathrm{mg} / \mathrm{kg}$, ip) or vehicle was administered 30 minutes prior to generalization testing and 30 minutes after pretreatment with I-THP (1.875 or $3.75 \mathrm{mg} / \mathrm{kg}$, ip) or vehicle. Testing was conducted as described above (section 2.5.1.).

\subsection{Statistical Analyses}

The effects of I-THP on breaking points for PR SA were examined using one-way repeated measures ANOVA when examining effects only at the $1.0 \mathrm{mg} / \mathrm{kg} / \mathrm{inf}$ cocaine dose or two-way cocaine dose (between subjects measure) $\times 1$-THP dose (repeated measure) ANOVA when comparing effects of $l$-THP at the 0.5 and $1.0 \mathrm{mg} / \mathrm{kg} / \mathrm{inf}$ doses. The effects of $I$-THP on breaking points and response rates during PR food SA were examined using two-way I-THP treatment (ITHP vs. vehicle; repeated measure) $\times I$-THP dose (between subjects measure) ANOVA. The effects of I-THP on the dose-response curve for cocaine generalization and response rate and on ( \pm ) 7-OH-DPAT substitution for cocaine during generalization testing were examined using 2-way ANOVA with cocaine dose as a repeated measure and ITHP dose as a between subjects measure for cocaine substitution and as a within subjects measure for $( \pm)$ 7-OH-DPAT substitution. Effective dose $50 \%\left(E_{50}\right)$ values for cocaine generalization alone or in combination with the two I-THP were calculated via non-linear regression using GraphPad Prism software based on the following equation used to generate a sigmoidal dose response curve: $Y=B$ Bottom $+($ Top-Bottom $) /\left(1+10^{\wedge}((\operatorname{LogEC} 50-\mathrm{X}))\right)$ where $\mathrm{X}$ is the logarithm of cocaine dose and $Y$ is the response, starting at Bottom and going to Top with a sigmoid shape. Effects of I-THP on ED 50 values were examined using one-way ANOVA. Bonferroni-corrected $t$-tests were

Pharmacology Biochemistry and Behavior, Vol. 97, No. 2 (December 2010): pg. 310-316. DOI. This article is (C) Elsevier and permission has been granted for this version to appear in e-Publications@Marquette. Elsevier does not grant permission for this article to be further copied/distributed or hosted elsewhere without the express permission from Elsevier. 
used for all post-hoc testing. In all cases statistical significance was defined as $\mathrm{P}<0.05$.

\section{Results}

\subsection{Progressive Ratio Cocaine Self-Administration}

Eighteen total rats were tested for the effects of I-THP on SA of $1.0 \mathrm{mg} / \mathrm{kg} / \mathrm{inf}$ cocaine under a PR schedule (Figure $1 \mathrm{~A}$ ). One-way repeated measures ANOVA showed a significant effect of I-THP on the breaking point for PR SA $\left(\mathrm{F}_{3,51}=8.136 ; \mathrm{P}<0.001\right)$. I-THP dosedependently reduced the breaking point for SA. Post-hoc testing using Bonferroni-corrected $t$-tests showed significant reductions in breaking point $(P<0.01)$ compared to vehicle pretreatment following administration of the 3.75 and $7.5 \mathrm{mg} / \mathrm{kg}$, but not $1.875, \mathrm{mg} / \mathrm{kg} /-$ THP at this self-administered cocaine dose.
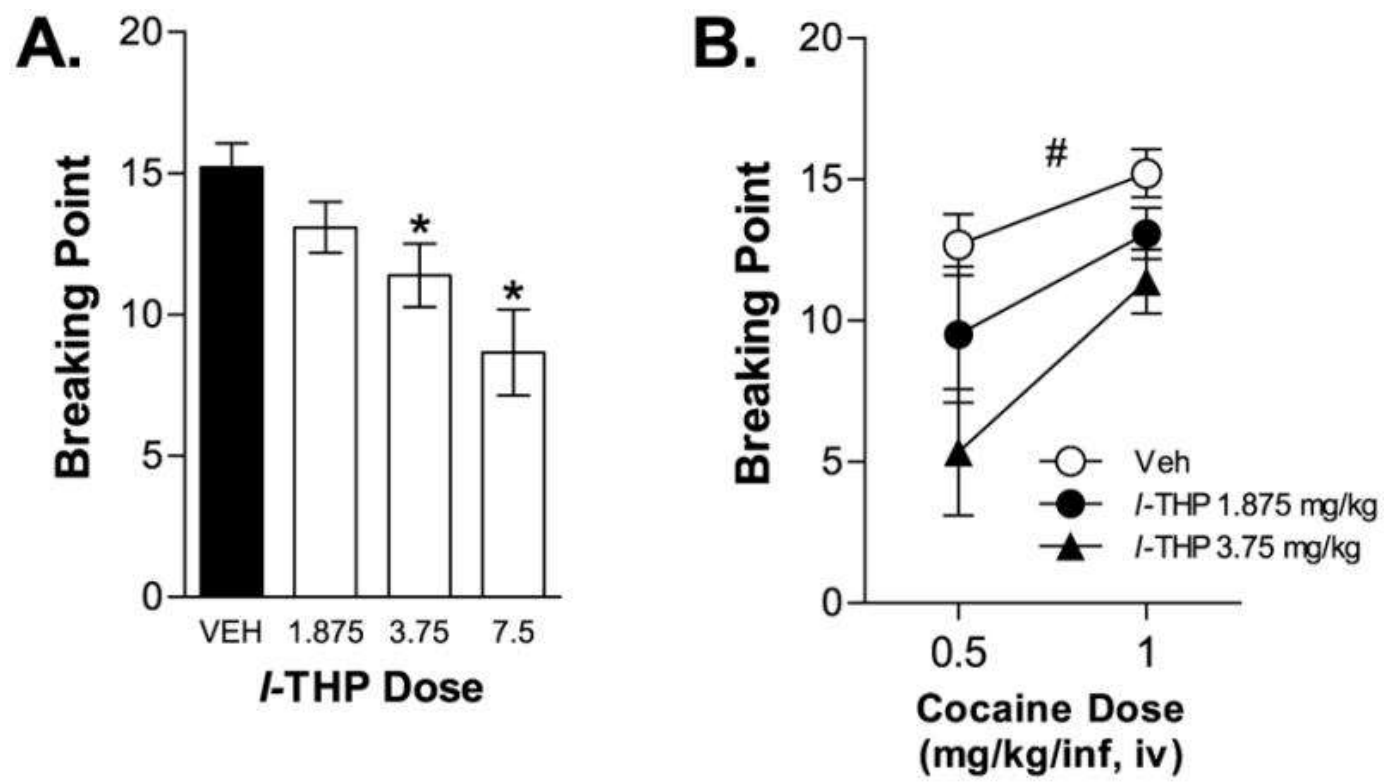

Figure 1 l-THP attenuated cocaine self-administration under a progressive ratio schedule of reinforcement. Data in Figure $1 \mathrm{~A}$ represent the mean breaking point (selfadministered infusions $\pm \mathrm{SE}$ ) during the SA session following pretreatment with I-THP $(1.875,3.75$, or $7.5 \mathrm{mg} / \mathrm{kg}$, ip) or vehicle (VEH) in rats self-administering 1.0 $\mathrm{mg} / \mathrm{kg} /$ inf cocaine $(\mathrm{n}=18 ; * \mathrm{P}<0.05 \mathrm{vs}$. VEH). Data in Figure 2B show the effects of ITHP (1.875 or 3.75) or vehicle (VEH) on breaking points in separate groups of rats self-administering $0.5(n=6)$ or $1.0(n=18) \mathrm{mg} / \mathrm{kg} / \mathrm{inf}$ cocaine $(\# P<0.05$; significant overall effects of 1.875 and $3.75 \mathrm{mg} / \mathrm{kg} \mathrm{I-THP} \mathrm{vs.} \mathrm{VEH).}$

Pharmacology Biochemistry and Behavior, Vol. 97, No. 2 (December 2010): pg. 310-316. DOI. This article is (C) Elsevier and permission has been granted for this version to appear in e-Publications@Marquette. Elsevier does not grant permission for this article to be further copied/distributed or hosted elsewhere without the express permission from Elsevier. 
NOT THE PUBLISHED VERSION; this is the author's final, peer-reviewed manuscript. The published version may be accessed by following the link in the citation at the bottom of the page.

To further examine the effects of I-THP on PR cocaine SA, a second group of rats $(n=6)$ was tested for the effects of 1.875 and $3.75 \mathrm{mg} / \mathrm{kg} /$-THP and vehicle on SA of a lower cocaine dose ( 0.5 $\mathrm{mg} / \mathrm{kg} / \mathrm{inf}$ ) under a PR schedule (Figure 1B). For statistical analysis, the breaking point for this group of rats was compared to rats tested for the effects of the same /-THP doses on SA of $1.0 \mathrm{mg} / \mathrm{kg} / \mathrm{inf}$ cocaine using a 2-way cocaine dose (between subjects measure) $\times 1$-THP dose (repeated measure) ANOVA. A significant overall effect of cocaine dose was observed $\left(F_{1,22}=6.112 ; P<0.05\right)$ with a higher breaking point observed at the higher cocaine dose, suggesting that these cocaine doses were located on the ascending limb of the SA dose-response curve. A significant overall effect of I-THP dose, but no interaction between I-THP dose and cocaine dose was also found $\left(F_{1,22}=22.553 ; P<0.001\right)$. I-THP dose-dependently reduced the breaking point for cocaine SA with significant overall reductions observed at both the 1.875 and $3.75 \mathrm{mg} / \mathrm{kg}$ doses $(P<0.05$; Bonferroni-corrected t-tests), consistent with a rightward and/or downward shift in the SA dose-response curve.

\subsection{Progressive Ratio Food Self-Administration}

To investigate the potential contribution of non-specific motor and anhedonic effects of I-THP to the observed reductions in breaking points for PR cocaine SA, separate groups of rats were tested for the effects of the $1.875,3.75$ and $7.5 \mathrm{mg} / \mathrm{kg} /$-THP doses on the SA of sucrose-sweetened food pellets under an identical PR schedule of reinforcement. Notably, under basal conditions, the breaking points for food and $1.0 \mathrm{mg} / \mathrm{kg} /$ inf cocaine did not significantly differ (15.20 \pm 0.84 for $1.0 \mathrm{mg} / \mathrm{kg} / \mathrm{inf}$ cocaine vs. $15.06 \pm 0.56$ for food $\mathrm{SA}$ ).

Thirteen rats were tested for the effects of 3.75 and $7.5 \mathrm{mg} / \mathrm{kg}$ I-THP on PR food SA. A separate group of six rats was tested for the effects of $1.875 \mathrm{mg} / \mathrm{kg}$ /-THP on PR food SA. The effects of I-THP on the breaking point for SA (i.e., the number of food pellets selfadministered under the PR schedule) are shown in Figure 2A. A 2-way I-THP treatment (I-THP vs. Veh; repeated measure) $\times 1$-THP dose condition $(1.875,3.75$. and $7.5 \mathrm{mg} / \mathrm{kg} /$-THP; between subjects measure) ANOVA showed a significant overall effect of I-THP treatment $\left(F_{1,29}=7.328 ; P<0.05\right)$, but not I-THP dose, on the breaking point for

Pharmacology Biochemistry and Behavior, Vol. 97, No. 2 (December 2010): pg. 310-316. DOI. This article is (C) Elsevier and permission has been granted for this version to appear in e-Publications@Marquette. Elsevier does not grant permission for this article to be further copied/distributed or hosted elsewhere without the express permission from Elsevier. 
PR food SA, and a significant I-THP treatment $\times$ dose interaction $\left(F_{2,29}=7.134 ; P<0.01\right)$. Post-hoc testing using Bonferroni-corrected ttests showed that a significant reduction in the breaking point for food SA compared to vehicle treatment was only observed at the $7.5 \mathrm{mg} / \mathrm{kg}$ I-THP dose $(\mathrm{P}<0.01)$.
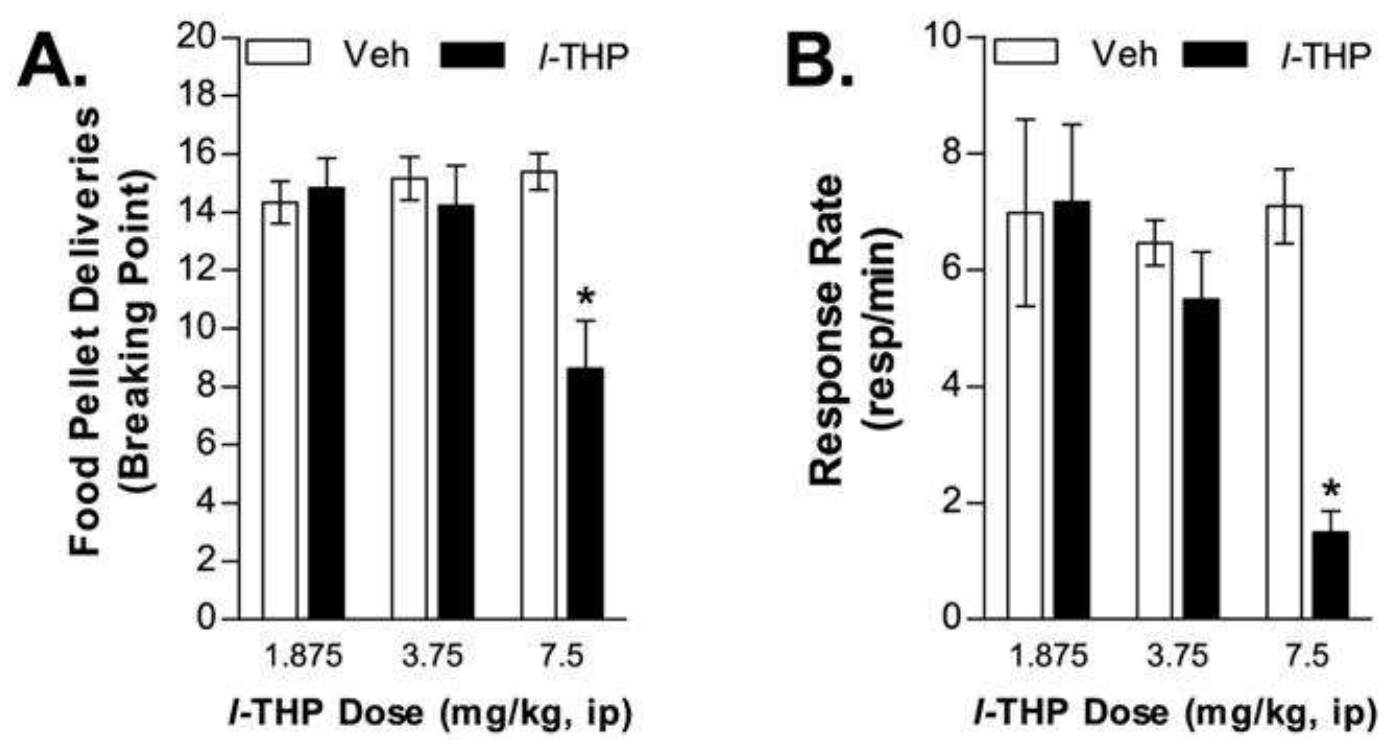

Figure 2 Effects of $I$-THP on breaking point and response rate in rats selfadministering sucrose-sweetened food pellets under a PR schedule. I-THP attenuated both breaking point and response rate, but only at the $7.5 \mathrm{mg} / \mathrm{kg}$ dose $(* \mathrm{P}<0.05 \mathrm{vs}$. $\mathrm{VEH}$ ). Data represent mean breaking points (food pellets acquired $\pm \mathrm{SE}$; Fig $2 \mathrm{~A}$ ) or response rates (resp/min $\pm \mathrm{SE}$; Fig $2 \mathrm{~B}$ ) during the PR SA sessions following pretreatment with $1.875(n=7), 3.75(n=13)$, or $7.5(n=13) \mathrm{mg} / \mathrm{kg}$ I-THP (ip) or vehicle (Veh).

Since effects on breaking point can be independent of effects on response rate, we also examined the effects of I-THP on the rate of lever pressing (responses per minute) during the food PR SA sessions (Figure 2B). A 2-way I-THP treatment (I-THP vs. Veh; repeated measure $) \times /$-THP dose condition $(1.875,3.75$. and $7.5 \mathrm{mg} / \mathrm{kg} \mathrm{l-THP \text {; }}$ between subjects measure) ANOVA showed significant main effects of I-THP treatment $\left(F_{1,29}=10.604 ; P<0.01\right)$ and I-THP dose $\left(F_{2,29}=6.289\right.$; $\mathrm{P}<0.01$ ) on response rate and a significant $/$-THP treatment $\times$ dose interaction $\left(F_{2,29}=8.246 ; P=0.001\right)$. Post-hoc testing showed that, similar to the effect on breaking point, reductions in response rate by I-THP compared to vehicle treatment were only observed at the 7.5 $\mathrm{mg} / \mathrm{kg}$ l-THP dose $(\mathrm{P}<0.001)$.

Pharmacology Biochemistry and Behavior, Vol. 97, No. 2 (December 2010): pg. 310-316. DOI. This article is (C) Elsevier and permission has been granted for this version to appear in e-Publications@Marquette. Elsevier does not grant permission for this article to be further copied/distributed or hosted elsewhere without the express permission from Elsevier. 
NOT THE PUBLISHED VERSION; this is the author's final, peer-reviewed manuscript. The published version may be accessed by following the link in the citation at the bottom of the page.

\subsection{Drug Discrimination}

Seven rats were used to examine the effects of vehicle and 3.75 and $7.5 \mathrm{mg} / \mathrm{kg} /$-THP on cocaine discrimination. A separate group of six rats was used to examine the effects of $1.875 \mathrm{mg} / \mathrm{kg} l$-THP on cocaine discrimination. Two-way l-THP dose (between subjects measure) $\times$ cocaine dose (repeated measure) ANOVA was used to examine the effects of $I$-THP on the dose-response curve for cocaine substitution for the $10 \mathrm{mg} / \mathrm{kg}$, ip training dose (Fig 3A). Significant overall effects of cocaine dose $\left(\mathrm{F}_{4,92}=109.540 ; \mathrm{P}<0.001\right)$ and $I$-THP dose $\left(F_{3,23}=16.659 ; P<0.001\right)$ and a significant cocaine dose $\times l$-THP dose interaction $\left(\mathrm{F}_{12,92}=10.092 ; \mathrm{P}<0.001\right)$ were found. Overall, dosedependent substitution for the cocaine training dose was observed. Post-hoc analysis showed that, overall, the 3.75 and 7.5, but not the $1.875, \mathrm{mg} / \mathrm{kg}$ doses of $\mathrm{I}$-THP attenuated cocaine generalization (Bonferroni-corrected t-test; $\mathrm{P}<0.001$ ). To further examine the effects of I-THP on cocaine-induced generalization, one-way ANOVA of I-THP effects followed by post-hoc testing was conducted at each individual cocaine dose. Effects of I-THP on cocaine-appropriate responding were observed at the $1.25 \mathrm{mg} / \mathrm{kg}\left(\mathrm{F}_{3,26}=3.076\right), 2.5 \mathrm{mg} / \mathrm{kg}\left(\mathrm{F}_{3,26}=16.272\right)$, and $5.0 \mathrm{mg} / \mathrm{kg}\left(F_{3,26}=15.472\right)$ doses, but not the 0 or $10 \mathrm{mg} / \mathrm{kg}$ doses, with post-hoc analyses revealing significant reductions by all three ITHP doses compared to vehicle at the $2.5 \mathrm{mg} / \mathrm{kg}$ cocaine dose and by the 3.75 and 7.5 , but not $1.875, \mathrm{mg} / \mathrm{kg} /$-THP doses at the $5.0 \mathrm{mg} / \mathrm{kg}$ cocaine dose (Bonferroni-corrected $t$-test; $\mathrm{P}<0.05$ ).
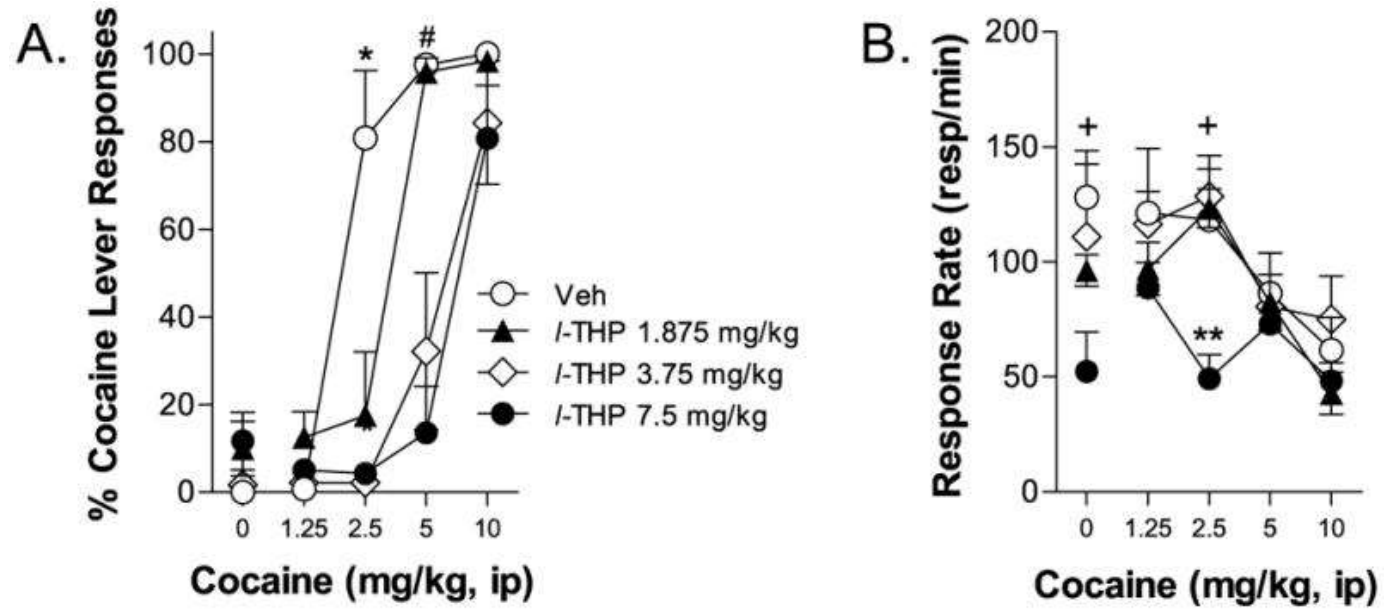

Figure 3 I-THP, at doses that did not alter response rate, dose-dependently attenuated cocaine-appropriate responding during generalization testing in rats trained

Pharmacology Biochemistry and Behavior, Vol. 97, No. 2 (December 2010): pg. 310-316. DOI. This article is (C) Elsevier and permission has been granted for this version to appear in e-Publications@Marquette. Elsevier does not grant permission for this article to be further copied/distributed or hosted elsewhere without the express permission from Elsevier. 
NOT THE PUBLISHED VERSION; this is the author's final, peer-reviewed manuscript. The published version may be accessed by following the link in the citation at the bottom of the page.

to discriminate cocaine $(10 \mathrm{mg} / \mathrm{kg}$, ip) from saline. Data in represent the mean percent responding on the cocaine-appropriate lever ( \pm SE; Fig $3 \mathrm{~A})$ and rate (resp/min; Fig 3B) during generalization testing during following administration of cocaine $(0-10 \mathrm{mg} / \mathrm{kg}$, ip) in rats pretreated with $1.875(n=6), 3.75(n=7)$ or 7.5 $(n=7) \mathrm{mg} / \mathrm{kg}$ I-THP (ip) or vehicle (Veh; $n=7)$. I-THP significantly attenuated cocaineappropriate responding at each dose tested $(* \mathrm{P}<0.05$ for each I-THP dose vs. Veh control; $\# \mathrm{P}<0.05,3.75$ and $7.5 \mathrm{mg} / \mathrm{kg}$ I-THP only vs. Veh) but only reduced response rate at the $7.5 \mathrm{mg} / \mathrm{kg}$ I-THP dose $(+\mathrm{P}<0.05$, significant overall effect of I-THP dose; $* * \mathrm{P}<0.05,7.5 \mathrm{mg} / \mathrm{kg} \mathrm{I-THP}$ only vs. Veh).

Since both doses of I-THP did not completely suppress, but rather produced a rightward shift in, the dose response curve for generalization, we were also able to generate and compare ED 50 values for cocaine-induced generalization in rats pretreated with I-THP or vehicle. $E_{50}$ values for cocaine generalization $(\mathrm{mg} / \mathrm{kg} \pm$ S.E.) were as follows: $2.16 \pm 0.24$ for vehicle pretreated rats; $4.04 \pm 1.24$ for rats pretreated with $1.875 \mathrm{mg} / \mathrm{kg}$ /-THP; $45.98 \pm 0.69$ for rats pretreated with $3.75 \mathrm{mg} / \mathrm{kg} /$-THP; and $7.83 \pm 1.24$ for rats pretreated with 7.5 $\mathrm{mg} / \mathrm{kg}$ I-THP. One-way ANOVA showed a significant effect of I-THP treatment condition on ED50 values for cocaine generalization $\left(F_{3,26}=12.031 ; P<0.001\right)$. Post-hoc testing using Bonferroni-corrected $t$-tests showed that the cocaine generalization $\mathrm{ED}_{50}$ was significantly increased in rats pretreated with the 3.75 and $7.5 \mathrm{mg} / \mathrm{kg} /$-THP doses, but not the $1.875 \mathrm{mg} / \mathrm{kg}$ /-THP dose compared to vehicle pretreated rats $(P<0.01$ for each comparison).

Two-way I-THP dose (between subjects measure) $\times$ cocaine dose (repeated measure) ANOVA was also used to examine the effects of I-THP on the rate of responding (resp/min) during generalization testing across the various cocaine doses (Fig 3B). A significant overall effects of cocaine dose $\left(F_{4,92}=9.003 ; P<0.001\right)$, but not I-THP dose, and a significant cocaine dose $\times$ l-THP dose interaction $\left(F_{12,92}=2.094 ; P<0.05\right)$ were found. Overall, response rate progressively decreased as the cocaine dose tested for generalization increased. Isolation of I-THP effects using one-way ANOVA at each cocaine dose showed that I-THP significantly altered response rate only at the $2.5 \mathrm{mg} / \mathrm{kg}$ cocaine dose ( $\mathrm{P}<0.05$ for each analysis). Post-hoc comparison (Bonferroni-corrected $t$-test) showed that the $7.5 \mathrm{mg} / \mathrm{kg}$, but not the $3.75 \mathrm{mg} / \mathrm{kg}$ or the 1.875, I-THP dose significantly reduced response rate $(P<0.01)$ when rats were tested at the $2.5 \mathrm{mg} / \mathrm{kg}$ cocaine dose. Despite a trend towards an I-THP induced reduction

Pharmacology Biochemistry and Behavior, Vol. 97, No. 2 (December 2010): pg. 310-316. DOI. This article is (C) Elsevier and permission has been granted for this version to appear in e-Publications@Marquette. Elsevier does not grant permission for this article to be further copied/distributed or hosted elsewhere without the express permi ssion from Elsevier. 
during vehicle testing $(P=0.055)$, statistically significant effects were not observed. Thus, although I-THP had rate-suppressing effects at the highest (i.e., $7.5 \mathrm{mg} / \mathrm{kg}$ ) dose tested, these effects were not found with the lower (i.e., 1.875 or $3.75 \mathrm{mg} / \mathrm{kg}$ ) I-THP doses, at which attenuation of cocaine's discriminative stimulus effects was observed.

To determine if the ability of I-THP to block DA D2/D3 receptors may have contributed to its effects on cocaine discrimination, the effects of I-THP (1.875 or $3.75 \mathrm{mg} / \mathrm{kg}$, ip) or vehicle on the substitution of the D2/D3 agonist, $( \pm)$ 7-OH-DPAT $(0,0.1,0.3$ and 1.0 $\mathrm{mg} / \mathrm{kg})$ for cocaine in rats $(\mathrm{n}=6)$ trained to discriminate $10 \mathrm{mg} / \mathrm{kg}$ cocaine from saline was examined (Figure 4). Two-way repeated measure $( \pm)$ 7-OH-DPAT dose $\times$ l-THP dose ANOVA examining $( \pm)$ 7$\mathrm{OH}$-DPAT substitution for cocaine, defined as responding on the cocaine-appropriate lever, showed significant overall effects of $( \pm) 7$ OH-DPAT $\left(\mathrm{F}_{3,15}=52.820 ; \mathrm{P}<001\right)$ and $\mathrm{l}$-THP $\left(\mathrm{F}_{2,10}=12.135 ; \mathrm{P}<0.01\right)$ and a significant $( \pm)$ 7-OH-DPAT dose $\times$ l-THP dose interaction $\left(F_{6,30}=4.770 ; P<0.01\right)$. I-THP dose-dependently substituted for cocaine with approximately 80 percent cocaine-appropriate responding at the two highest I-THP doses. Post-hoc analysis showed significant overall reductions in cocaine-appropriate responding after $( \pm)$ 7-OH-DPAT administration following pretreatment with either I-THP dose tested ( $P<0.05$ for each; Bonferroni-corrected t-tests). Effects of I-THP at each $( \pm)$ 7-OH-DPAT dose were further examined using one-way repeated measures ANOVA. A significant I-THP effect was found at the $0.3 \mathrm{mg} / \mathrm{kg}( \pm) 7-\mathrm{OH}-\mathrm{DPAT}$ dose $\left(\mathrm{F}_{2,10}=23.280 ; \mathrm{P}<0.001\right)$, but not the other doses, with significant reductions in cocaine-appropriate responding compared to vehicle observed at each I-THP dose tested $(\mathrm{P}<0.05$ for each; Bonferroni- corrected t-tests).

Pharmacology Biochemistry and Behavior, Vol. 97, No. 2 (December 2010): pg. 310-316. DOI. This article is (c) Elsevier and permission has been granted for this version to appear in e-Publications@Marquette. Elsevier does not grant permission for this article to be further copied/distributed or hosted elsewhere without the express permission from Elsevier. 


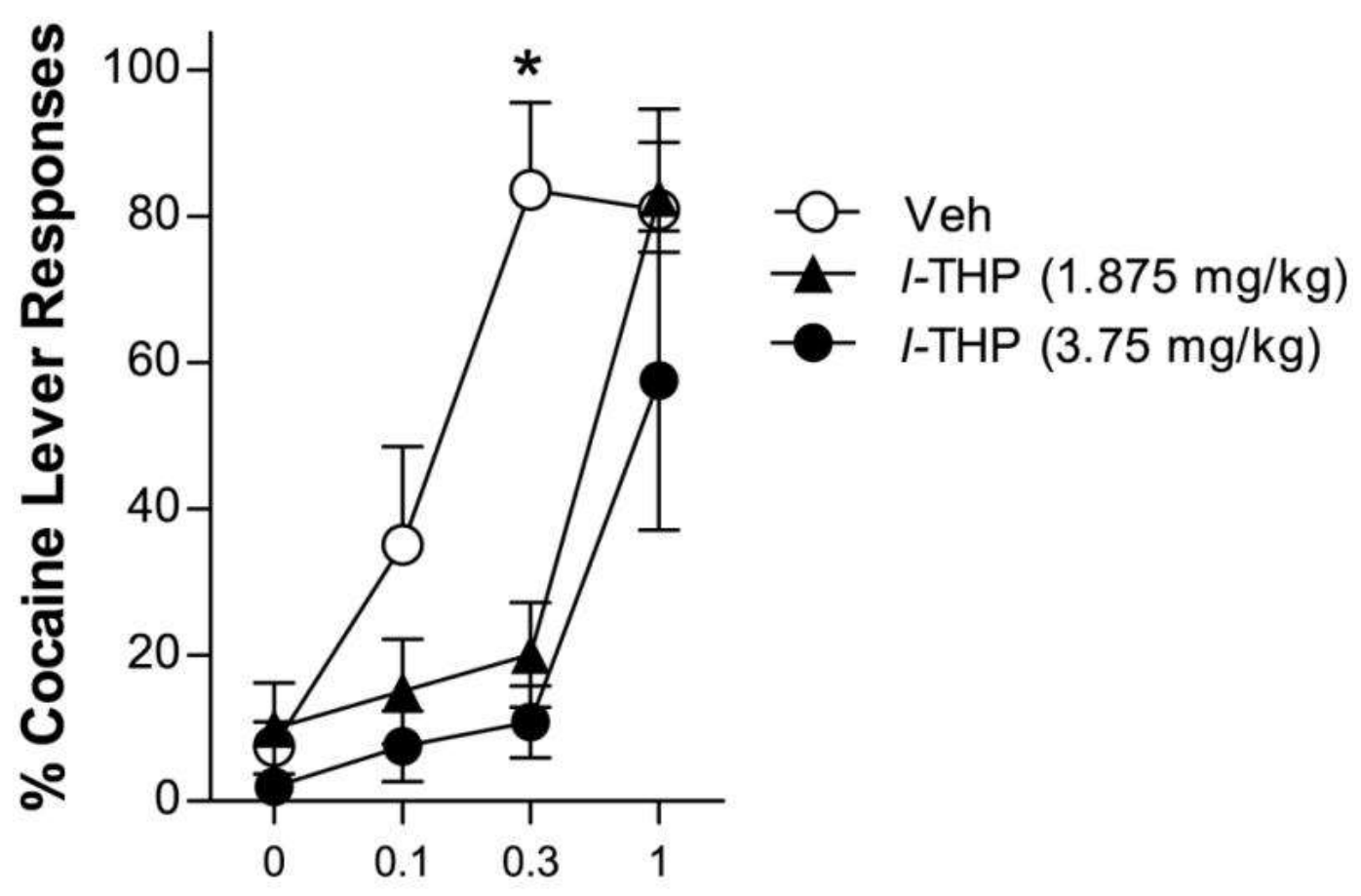

\section{7-OH-DPAT (mg/kg, ip)}

Figure 4 l-THP dose-dependently attenuated substitution of $( \pm)$ 7-OH-DPAT for cocaine in rats $(n=6)$ trained to discriminate cocaine $(10 \mathrm{mg} / \mathrm{kg}$, ip) from saline. Data in represent the mean percent responding on the cocaine-appropriate lever ( $\pm \mathrm{SE})$ during the generalization sessions following administration of $( \pm$ ) 7-OH-DPAT (0-1 $\mathrm{mg} / \mathrm{kg}$, ip) in rats pretreated with I-THP (1.875 or $3.75 \mathrm{mg} / \mathrm{kg}$, ip) or vehicle (Veh). $( \pm)$ 7-OH-DPAT dose-dependently substituted for cocaine. At the $0.3 \mathrm{mg} / \mathrm{kg}( \pm) 7-\mathrm{OH}-$ DPAT dose, substitution was significantly reduced compared to Veh pretreated rats by both I-THP doses $(* \mathrm{P}<0.05)$.

\section{Discussion}

Previously we and others reported that I-THP attenuated cocaine SA under FR (Mantsch et al., 2007; Xi et al., 2007) and PR ( $\underline{\text { Xi et al., }}$ 2007) schedules, cocaine-evoked reinstatement (Mantsch et al., 2007) and cocaine-induced reductions in ICSS thresholds (Xi et al., 2007), suggesting that I-THP may have potential as a pharmacotherapeutic agent for use in drug-dependent populations. The present study extends these findings to include attenuation of cocaine's discriminative stimulus effects and further demonstrates that attenuation of cocaine's reinforcing and subjective effects by I-THP can likely be accomplished at doses that do not produce marked motor impairment or anhedonic effects and may therefore be well tolerated.

Pharmacology Biochemistry and Behavior, Vol. 97, No. 2 (December 2010): pg. 310-316. DOI. This article is (C) Elsevier and permission has been granted for this version to appear in e-Publications@Marquette. Elsevier does not grant permission for this article to be further copied/distributed or hosted elsewhere without the express permi ssion from Elsevier. 
The effects of I-THP on cocaine's discriminative stimulus and reinforcing effects most likely stem from its actions at DA receptors (Jin, 1987). Roles for DA in cocaine's discriminative stimulus (Callahan et al., 1997) and reinforcing (Anderson and Pierce, 2005) effects have been well established. Drugs that interfere with DA actions at D1 (Kleven et al., 1988; Barrett and Appel, 1989; Kleven et al., 1990; Vanover et al., 1991; Witkin et al., 1991; Sinnott and Nader, 2001), D2 (Barrett and Appel, 1989; Kleven et al., 1990; Costanza et al., 2001), or D3 (Beardsley et al., 2001; Martelle et al., 2007) DA receptors through antagonism or partial agonism have been reported to attenuate cocaine's discriminative stimulus properties, while agonists at D1 (Callahan et al., 1991; Spealman et al., 1991; Witkin et al., 1991; Sinnott and Nader, 2001; Chausmer and Katz, 2002), D2 (Callahan et al., 1991; Spealman et al., 1991; Witkin et al., 1991; Callahan and Cunningham, 1993; Katz and Witkin, 1992), or D3 (Acri et al., 1995; Lamas et al., 1996; Spealman, 1996; Sinnot et al., 1999) receptors have been reported to promote cocaine generalization in drug discrimination protocols. Likewise D1 (Hubner and Moreton, 1991; Depoortere et al., 1993), D2 (Roberts et al., 1989; Hubner and Moreton, 1991) and D3 (Xi et al., 2005; 2006) DA receptor antagonists have been reported to reduce breaking points for cocaine SA under a PR schedule, while D1 (Rowlett et al., 2007), D2 (Rowlett et al., 2007), and D3 (Caine and Koob, 1995) receptor agonists have been reported to have the opposite effect.

A large body of data suggests that I-THP binds to D1 and D2 DA receptors (Jin, 1987; Guo et al., 1997; Mantsch et al., 2007), likely functioning as an antagonist as measured using a number of indices (Jin et al., 1986; Xu et al., 1989; Wu et al., 1990; Zhu et al., 1991; Huang and Jin, 1992; Sun et al., 1992; Hu and Jin, 1999; Mantsch et al., 2007). We have also found that I-THP binds to the D3 receptor (Mantsch et al., 2007) at concentrations reached in the brain following systemic administration of doses comparable to those used in the present study ( To examine the potential role of I-THP antagonism of D2 and D3 receptors in its effects, we examined the ability of I-THP to block substitution of the D2/D3 agonist, ( \pm ) 7-OH-DPAT, for cocaine. As has been previously reported (Acri et al., 1995; Lamas et al., 1996; Baker et al., 1998; Sinnott et al., 1999; Caine et al., 2000; Ukai et al., 2005), ( \pm ) 7-OH-DPAT dose-dependently substituted for cocaine. Like

Pharmacology Biochemistry and Behavior, Vol. 97, No. 2 (December 2010): pg. 310-316. DOI. This article is (C) Elsevier and permission has been granted for this version to appear in e-Publications@Marquette. Elsevier does not grant permission for this article to be further copied/distributed or hosted elsewhere without the express permission from Elsevier. 
cocaine, the dose-response curve for $( \pm)$ 7-OH-DPAT substitution was shifted to the right by I-THP pretreatment. Although 7-OH-DPAT has approximately a 100-fold higher affinity for D3 receptors relative to D2 receptors (Lévesque et al., 1992) it has been found that both D2 and D3 receptors contribute to its cocaine-like discriminative stimulus effects (Baker et al., 1998; Garner and Baker, 1999; Ukai et al., 2005), suggesting a possible role for D2 and/or D3 antagonism in the effects of I-THP. Determination of the relative role of D2 vs. D3 receptor antagonism, as well as the role of D1 receptor antagonism in the effects of I-THP on cocaine discrimination, will require further investigation.

While we consider it likely that the effects of I-THP on cocaine discrimination and SA are attributable to DA receptor antagonism, it should be noted that I-THP does interact with a number of other receptors, including alpha-1 adrenergic receptors, at which it functions as an antagonist ( Lu et al., 1996), and gamma-aminobutyric acid $(\mathrm{GABA})_{\mathrm{A}}$ receptors, at which it facilitates GABA binding through positive allosteric effects (Halbsguth et al., 2003). The contribution of these mechanisms to the effects of I-THP will require further investigation. Despite its use as an analgesic agent, no interaction of ITHP with opioid receptors has been documented, and its analgesic effects are naloxone-independent ( $\mathrm{Hu}$ and Jin, 1999).

Consistent with the findings of $\mathrm{Xi}$ et al (2007) I-THP dosedependently reduced cocaine SA under a PR schedule. The effects of ITHP on PR cocaine SA appeared to represent a rightward shift in the dose-responses curve, consistent with a reduction in cocaine's reinforcing effects and similar to the rightward shift in FR cocaine SA following I-THP administration observed by Xi et al. (2007). Effects on PR cocaine SA were observed at each I-THP dose tested, although significant effects of the $1.875 \mathrm{mg} / \mathrm{kg}$ dose of I-THP were only observed when examined as an overall effect across both cocaine doses. Notably, Xi et al. (2007) found effects on both PR and FR cocaine SA at I-THP doses as low as $1 \mathrm{mg} / \mathrm{kg}$ (ip). By contrast, effects on both response rate and breaking points for food SA under an identical PR schedule were only observed at the highest I-THP dose tested (i.e., $7.5 \mathrm{mg} / \mathrm{kg}$ ). Importantly, the reinforcing efficacies of cocaine and food were matched in this study such that breaking points were equivalent in the absence of I-THP treatment. These findings

Pharmacology Biochemistry and Behavior, Vol. 97, No. 2 (December 2010): pg. 310-316. DOI. This article is (C) Elsevier and permission has been granted for this version to appear in e-Publications@Marquette. Elsevier does not grant permission for this article to be further copied/distributed or hosted elsewhere without the express permission from Elsevier. 
support our previous findings that I-THP attenuated cocaine SA under a FR schedule and cocaine-induced reinstatement at doses that failed to alter concurrently measured food- or sucrose-reinforced lever pressing under FR schedules (Mantsch et al., 2007; Xi et al., 2007). Likewise, in our drug discrimination experiment, I-THP failed to alter response rate during generalization testing at a doses (i.e., 1.875 and $3.75 \mathrm{mg} / \mathrm{kg}$ ) that significantly attenuated cocaine generalization. Although we have previously found that the $3.75 \mathrm{mg} / \mathrm{kg}$ dose of I-THP reduces locomotor activity (Mantsch et al., 2007), Xi et al. (2007) reported that a comparable dose of $I$-THP (i.e., $3 \mathrm{mg} / \mathrm{kg}$, ip) has no effect.

The viability of DA antagonist drugs as medications for cocaine addiction has been greatly limited by a range of side effects, including sedation and anhedonia. Further, I-THP-containing preparations have been used for their sedative properties and the primary clinical feature of overdose intoxication with such preparations is central nervous system depression ( Horowitz et al., 1996). The observed dose separation between the effects of I-THP on drug seeking and motoric effects as measured by lever pressing for a non-drug reinforcer or locomotor activity and potential anhedonic effects as measured by sucrose-sweetened pellet PR SA breaking points and ICSS thresholds (Xi et al., 2007) suggests that I-THP may have more desirable safety profile when compared to other DA antagonist drugs. Although the efficacy and safety of I-THP in human cocaine-dependent populations has not been reported, the potential utility of I-THP for the treatment of addiction is supported by the findings of a recent preliminary clinical trial suggesting that I-THP may reduce drug craving and relapse in recovering heroin addicts (Yang et al., 2008). Clinical testing of I-THP effectiveness in the US awaits further examination of its safety for use in human populations.

\subsection{Conclusions}

To summarize, the present findings extend previous preclinical findings (Mantsch et al., 2007; Xi et al., 2007) and support the recent clinical report (Yang et al., 2008) suggesting that I-THP has therapeutic utility for the treatment of addiction. Although sedative properties of I-THP may limit its use, we were able to attenuate

Pharmacology Biochemistry and Behavior, Vol. 97, No. 2 (December 2010): pg. 310-316. DOI. This article is (C) Elsevier and permission has been granted for this version to appear in e-Publications@Marquette. Elsevier does not grant permission for this article to be further copied/distributed or hosted elsewhere without the express permission from Elsevier. 
cocaine's discriminative stimulus and reinforcing effects at I-THP doses that had little or no effects on food-reinforced responding during the same session, in the case of the drug discrimination experiment, or in separate rats self-administering food pellets under an identical PR schedule. Characterization of the unique pharmacological effects of ITHP and other similar compounds, in particular their actions at DA receptors, may provide insight into drug profiles and/or combinations that may be effective for managing cocaine addiction.

\section{Acknowledgments}

Funding for the study was provided by National Institute on Drug Abuse (NIDA) grant number DA015758 and National Center for Complementary and Alternative Medicine (NCCAM) grant number AT004736 to JRM and NIDA grant number DA017328 to DAB. The authors thank Christopher Mueller for his technical assistance.

\section{Footnotes}

Publisher's Disclaimer: This is a PDF file of an unedited manuscript that has been accepted for publication. As a service to our customers we are providing this early version of the manuscript. The manuscript will undergo copyediting, typesetting, and review of the resulting proof before it is published in its final citable form. Please note that during the production process errors may be discovered which could affect the content, and all legal disclaimers that apply to the journal pertain.

\section{References}

1. Acri JB, Carter SR, Alling K, Geter-Douglass B, Dijkstra D, Wikstrom H, et al. Assessment of cocaine- like discriminative stimulus effects of dopamine D3 receptor ligands. Eur J Pharmacol. 1995;281:R7-9.

2. Anderson SM, Pierce RC. Cocaine-induced alterations in dopamine receptor signaling: implications for reinforcement and reinstatement. Pharmacol Ther. 2005;106:389-403.

3. Baker LE, Svensson KA, Garner KJ, Goodwin AK. The dopamine D3 receptor antagonist PNU-99194A fails to block (+)-7-OH-DPAT substitution for D-amphetamine or cocaine. Eur J Pharmacol. 1998;358:101-9.

Pharmacology Biochemistry and Behavior, Vol. 97, No. 2 (December 2010): pg. 310-316. DOI. This article is (C) Elsevier and permission has been granted for this version to appear in e-Publications@Marquette. Elsevier does not grant permission for this article to be further copied/distributed or hosted elsewhere without the express permission from Elsevier. 
NOT THE PUBLISHED VERSION; this is the author's final, peer-reviewed manuscript. The published version may be accessed by following the link in the citation at the bottom of the page.

4. Barrett RL, Appel JB. Effects of stimulation and blockade of dopamine receptor subtypes on the discriminative stimulus properties of cocaine. Psychopharmacol. 1989;99:13-6.

5. Beardsley PM, Sokoloff P, Balster RL, Schwartz JC. The D3R partial agonist, BP 897, attenuates the discriminative stimulus effects of cocaine and Damphetamine and is not self-administered. Behav Pharmacol. 2001;12:111.

6. Caine SB, Koob GF. Pretreatment with the dopamine agonist 7-OH-DPAT shifts the cocaine self-administration dose-effect function to the left under different schedules in the rat. Behav Pharmacol. 1995;6:333-47.

7. Caine SB, Negus SS, Mello NK, Bergman J. Effects of dopamine D1-like and D2-like agonists in rats trained to discriminate cocaine from saline: influence of experimental history. Exp Clin Psychopharmacol. 2000;8:40414.

8. Callahan PM, Appel JB, Cunningham KA. Dopamine D1 and D2 mediation of the discriminative stimulus properties of $d$-amphetamine and cocaine. Psychopharmacol. 1991;103:50-5.

9. Callahan PM, Cunningham KA. Discriminative stimulus properties of cocaine in relation to dopamine D2 receptor function in rats. J Pharmacol Exp Ther. 1993;266:585-9.

10. Callahan PM, De La Garza R, 2nd, Cunningham KA. Mediation of the discriminative stimulus properties of cocaine by mesocorticolimbic dopamine systems. Pharmacol Biochem Behav. 1997;57:601-7.

11. Chausmer AL, Katz JL. Comparison of interactions of D1-like agonists, SKF 81297, SKF 82958, and A-77636, with cocaine: locomotor activity and drug discrimination studies in rodents. Psychopharmacol. 2002; 159:145-53.

12. Chu H, Jin G, Friedman $E$, Zhen X. Recent development in studies of tetrahydroprotoberberines: mechanism in antinociception and drug addiction. Cell Mol Neurobiol. 2008;28:491-9.

13. Costanza RM, Barber DJ, Terry P. Antagonism of the discriminative stimulus effects of cocaine at two training doses by dopamine D2-like receptor antagonists. Psychopharmacol. 2001;158:146-53.

Pharmacology Biochemistry and Behavior, Vol. 97, No. 2 (December 2010): pg. 310-316. DOI. This article is (C) Elsevier and permission has been granted for this version to appear in e-Publications@Marquette. Elsevier does not grant permission for this article to be further copied/distributed or hosted elsewhere without the express permission from Elsevier. 
NOT THE PUBLISHED VERSION; this is the author's final, peer-reviewed manuscript. The published version may be accessed by following the link in the citation at the bottom of the page.

14. Depoortere RY, Li DH, Lane JD, Emmett-Oglesby MW. Parameters of selfadministration of cocaine in rats under a progressive-ratio schedule. Pharmacol Biochem Behav. 1993;45:539-48.

15. De Smet PA. Herbal remedies. N Engl J Med. 2002;347:2046-56.

16. Ding GS. Important Chinese herbal remedies. Clin Ther. 1987;9:345-57.

17. Ernst E. The efficacy of herbal medicine-an overview. Fundam Clin Pharmacol. 2005;19:405-9.

18. Garner KJ, Baker LE. Analysis of D2 and D3 receptor-selective ligands in rats trained to discriminate cocaine from saline. Pharmacol Biochem Behav. 1999;64:373-8.

19. Guo X, Wang LM, Liu J, Jin GZ. Characteristics of tetrahydroprotoberberines on dopamine D1 and D2 receptors in calfstriatum. Zhongguo Yao Li Xue Bao. 1997;18:225-30.

20. Halbsguth C, Meissner O, Haberlein H. Positive cooperation of protoberberine type 2 alkaloids from Corydalis cava on the GABAA binding site. Planta Med. 2003;69:305-9.

21. Hong Z, Fan G, Le J, Chai Y, Yin X, Wu Y. Brain pharmacokinetics and tissue distribution of tetrahydropalmatine enantiomers in rats after oral administration. Biopharm Drug Dispos. 2006;27:111-117.

22. Horowitz RS, Feldhaus K, Dart RC, Stermitz FR, Beck JJ. The clinical spectrum of Jin Bu Huan toxicity. Arch Intern Med. 1996;156:899-903.

23. Hu JY, Jin GZ. Supraspinal D2 receptor involved in antinociception induced by I-tetrahydropalmatine. Zhongguo Yao Li Xue Bao. 1999;20:715-9.

24. Huang KX, Jin GZ. The antagonistic effects of tetrahydroprotoberberines on dopamine receptors: electrophysiological studies. Sci China B. $1992 ; 35: 688-96$

25. Hubner CB, Moreton JE. Effects of selective D1 and D2 dopamine antagonists on cocaine self-administration in the rat. Psychopharmacol. $1991 ; 105: 151-6$.

26. Jin GZ, Yu SX, Yu LP. Different effects of enantiomers of tetrahydropalmatine on dopaminergic system. Sci Sin. 1986;29:1054-64.

Pharmacology Biochemistry and Behavior, Vol. 97, No. 2 (December 2010): pg. 310-316. DOI. This article is (C) Elsevier and permission has been granted for this version to appear in e-Publications@Marquette. Elsevier does not grant permission for this article to be further copied/distributed or hosted elsewhere without the express permission from Elsevier. 
NOT THE PUBLISHED VERSION; this is the author's final, peer-reviewed manuscript. The published version may be accessed by following the link in the citation at the bottom of the page.

27. Jin GZ. (-)-Tetrahydropalmatine and its analogues as new dopamine receptor antagonists. Trends Pharmacol Sci. 1987;8:81-2.

28. Jin GZ, Zhu ZT, Fu Y. (-)-Stepholidine: a potential novel antipsychotic drug with dual D1 receptor agonist and D2 receptor antagonist actions. Trends Pharmacol Sci. 2002;23:4-7.

29. Katz JL, Witkin JM. Behavioral effects of dopaminergic agonists and antagonists alone and in combination in the squirrel monkey. Psychopharmacol. 1993;113:19-25.

30. Kleven MS, Anthony EW, Goldberg LI, Woolverton WL. Blockade of the discriminative stimulus effects of cocaine in rhesus monkeys with the D1 dopamine antagonist SCH 23390. Psychopharmacol. 1988;95:427-9.

31. Kleven MS, Anthony EW, Woolverton WL. Pharmacological characterization of the discriminative stimulus effects of cocaine in rhesus monkeys. J Pharmacol Exp Ther. 1990;254:312-7.

32. Lamas X, Negus SS, Nader MA, Mello NK. Effects of the putative dopamine D3 receptor agonist 7-OH-DPAT in rhesus monkeys trained to discriminate cocaine from saline. Psychopharmacol. 1996;124:306-14.

33. Lévesque D, Diaz J, Pilon C, Martres MP, Giros B, Souil E, Schott D, Morgat JL, Schwartz JC, Sokoloff P. Identification, characterization, and localization of the dopamine D3 receptor in rat brain using 7-[3H]hydroxyN,N-di-n-propyl-2-aminotetralin. Proc Natl Acad Sci USA. 1992;89:81559.

34. Liu YL, Yan LD, Zhou PL, Wu CF, Gong ZH. Levo-tetrahydropalmatine attenuates oxycodone-induced conditioned place preference in rats. Eur J Pharmacol. 2009;602:321-7.

35. Lu ZZ, Wei X, Jin GZ, Han QD. Antagonistic effects of tetrahydroprotoberberine homologues on alpha-1 adrenoceptor. Yao Xue Xue Bao. 1996;31:652-6.

36. Mantsch JR, Goeders NE. Ketoconazole does not block cocaine discrimination or the cocaine-induced reinstatement of cocaine-seeking behavior. Pharmacol Biochem Behav. 1999;64:65-73.

Pharmacology Biochemistry and Behavior, Vol. 97, No. 2 (December 2010): pg. 310-316. DOI. This article is (C) Elsevier and permission has been granted for this version to appear in e-Publications@Marquette. Elsevier does not grant permission for this article to be further copied/distributed or hosted elsewhere without the express permission from Elsevier. 
NOT THE PUBLISHED VERSION; this is the author's final, peer-reviewed manuscript. The published version may be accessed by following the link in the citation at the bottom of the page.

37. Mantsch JR, Li SJ, Risinger R, Awad S, Katz E, Baker DA, et al. Levotetrahydropalmatine attenuates cocaine self-administration and cocaineinduced reinstatement in rats. Psychopharmacology. 2007;192:581-91.

38. Platt DM, Rowlett JK, Spealman RD. Behavioral effects of cocaine and dopaminergic strategies for preclinical medication development.

Psychopharmacol. 2002;163:265-82.

39. Richardson NR, Roberts DCS. Progressive ratio schedules in drug selfadministration studies in rats: A method to evaluate reinforcing efficacy. J Neurosci Methods. 1996;66:1-11.

40. Roberts DC, Loh EA, Vickers G. Self-administration of cocaine on a progressive ratio schedule in rats: dose-response relationship and effect of haloperidol pretreatment. Psychopharmacology. 1989;97:535-8.

41. Rowlett JK, Platt DM, Yao WD, Spealman RD. Modulation of heroin and cocaine self-administration by dopamine D1- and D2-like receptor agonists in rhesus monkeys. J Pharmacol Exp Ther. 2007;321:1135-43.

42. Sinnott RS, Nader MA. Modulation of cocaine's discriminative stimulus effects by dopamine $D(1)$ agonists in rhesus monkeys. Pharmacol Biochem Behav. 2001;68:301-9.

43. Spealman RD, Bergman J, Madras BK, Melia KF. Discriminative stimulus effects of cocaine in squirrel monkeys: involvement of dopamine receptor subtypes. J Pharmacol Exp Ther. 1991;258:945-53.

44. Sun BC, Huang KX, Jin GZ. Comparison of effects of tetrahydropalmatine enantiomers on firing activity of dopamine neurons in substantia nigra pars compacta. Zhongguo Yao Li Xue Bao. 1992;13:292-7.

45. Ukai M, Mitsunaga $H$. Involvement of dopamine D3 and D4 receptors in the discriminative stimulus properties of cocaine in the rat. Methods Find Exp Clin Pharmacol. 2005;27:645-9.

46. Vanover KE, Kleven MS, Woolverton WL. Blockade of the discriminative stimulus effects of cocaine in rhesus monkeys with the $D(1)$ dopamine antagonists SCH-39166 and A-66359. Behav Pharmacol. 1991;2:151-9.

47. Vocci FJ, Acri J, Elkashef A. Medication development for addictive disorders: the state of the science. Am J Psychiatry. 2005;162:1432-40.

Pharmacology Biochemistry and Behavior, Vol. 97, No. 2 (December 2010): pg. 310-316. DOI. This article is (C) Elsevier and permission has been granted for this version to appear in e-Publications@Marquette. Elsevier does not grant permission for this article to be further copied/distributed or hosted elsewhere without the express permission from Elsevier. 
NOT THE PUBLISHED VERSION; this is the author's final, peer-reviewed manuscript. The published version may be accessed by following the link in the citation at the bottom of the page.

48. Volkow ND, Fowler JS, Wang GJ, Swanson JM. Dopamine in drug abuse and addiction: results from imaging studies and treatment implications. Mol Psychiatry. 2004;9:557-69.

49. Witkin JM, Nichols DE, Terry P, Katz JL. Behavioral effects of selective dopaminergic compounds in rats discriminating cocaine injections. J Pharmacol Exp Ther. 1991;257:706-13.

50. Wu G, Jiang JW, Wu GC, Cao XD. Effects of four dopamine agonists on Itetrahydropalmatine-induced analgesia and electroacupuncture analgesia in rabbits. Zhongguo Yao Li Xue Bao. 1990;11:196-200.

51. Xi ZX, Gilbert JG, Pak AC, Ashby CR, Jr, Heidbreder CA, Gardner EL. Selective dopamine D3 receptor antagonism by SB-277011A attenuates cocaine reinforcement as assessed by progressive-ratio and variable-costvariable-payoff fixed-ratio cocaine self-administration in rats. Eur J Neurosci. 2005;21:3427-38.

52. Xi ZX, Newman AH, Gilbert JG, Pak AC, Peng XQ, Ashby CR, Jr, et al. The novel dopamine D3 receptor antagonist NGB 2904 inhibits cocaine's rewarding effects and cocaine-induced reinstatement of drug-seeking behavior in rats. Neuropsychopharmacology. 2006;31:1393-405.

53. Xi ZX, Yang Z, Li SJ, Li X, Dillon C, Peng XQ, et al. Levotetrahydropalmatine inhibits cocaine's rewarding effects: experiments with self-administration and brain-stimulation reward in rats. Neuropharmacology. 2007;53:771-82.

54. Xu SX, Yu LP, Han YR, Chen Y, Jin GZ. Effects of tetrahydroprotoberberines on dopamine receptor subtypes in brain. Zhongguo Yao Li Xuebao. 1989;10:104-10.

55. Yang Z, Shao YC, Li SJ, Qi JL, Zhang MJ, Hao W, et al. Medication of Itetrahydropalmatine significantly ameliorates opiate craving and increases the abstinence rate in heroin users: a pilot study. Acta Pharmacol Sin. $2008 ; 29: 781-8$.

56. Zhu XZ, Zhou Z, Ji XQ, Gu J, Luo LG, Wang FS. I-tetrahydropalmatine increases leucine enkephalin levels in corpus striatum of rats. Zhongguo Yao Li Xue Bao. 1991;12:104-7.

Corresponding author: John R. Mantsch, Ph.D., Department of Biomedical Sciences, Marquette University, Schroeder Health Complex, P.O. Box 1881,

Pharmacology Biochemistry and Behavior, Vol. 97, No. 2 (December 2010): pg. 310-316. DOI. This article is (C) Elsevier and permission has been granted for this version to appear in e-Publications@Marquette. Elsevier does not grant permission for this article to be further copied/distributed or hosted elsewhere without the express permission from Elsevier. 
NOT THE PUBLISHED VERSION; this is the author's final, peer-reviewed manuscript. The published version may be accessed by following the link in the citation at the bottom of the page.

Milwaukee, WI 53201-1881, USA, Tel: (414) 288-2036, Fax: (414) 288-6564, Email: john.mantsch@marquette.edu

Pharmacology Biochemistry and Behavior, Vol. 97, No. 2 (December 2010): pg. 310-316. DOI. This article is (C) Elsevier and permission has been granted for this version to appear in e-Publications@Marquette. Elsevier does not grant permission for this article to be further copied/distributed or hosted elsewhere without the express permission from Elsevier. 